\title{
An Opportunistic Pantoea sp. Isolated from a Cotton Fleahopper That Is Capable of Causing Cotton (Gossypium hirsutum L.) Bud Rot
}

\author{
Enrique G. Medrano*, Alois A. Bell \\ United States Department of Agriculture, Agricultural Research Service, College Station, TX, USA \\ Email: *gino.medrano@ars.usda.gov
}

How to cite this paper: Medrano, E.G. and Bell, A.A. (2017) An Opportunistic Pantoea sp. Isolated from a Cotton Fleahopper That Is Capable of Causing Cotton (Gossypium hirsutum L.) Bud Rot. Agricultural Sciences, 8, 64-76.

http://dx.doi.org/10.4236/as.2017.81006

Received: December 6, 2016

Accepted: January 16, 2017

Published: January 19, 2017

Copyright $\odot 2017$ by authors and Scientific Research Publishing Inc. This work is licensed under the Creative Commons Attribution International License (CC BY 4.0).

http://creativecommons.org/licenses/by/4.0/

\begin{abstract}
Pantoea ananatis (Serrano) representatives are known to have a broad host range including both humans and plants. The cotton fleahopper (Pseudatomoscelis seriatus, Reuter) is a significant pest that causes cotton bud damage that may result in significant yield losses. In this study, a bacterial strain previously isolated from a fleahopper was tested for cotton infectivity using simulated insect feeding. In addition, cotton fleahoppers collected from the field were raised on green beans in the laboratory to test the insects' capacity to vector cotton pathogens. Adult insects were then caged with greenhouse grown cotton buds. Buds that remained or abscised from the plants following feeding by the insect consistently showed necrosis of the ovary including the wall. A collection of bacterial isolates from both caged insects and diseased buds was analyzed using carbon utilization and enzyme production tests, fatty acid methyl ester profile analysis, and by cloning and sequencing 16S RNA genes. Results showed that the majority of the isolates were best classified as $P$. ananatis. Upon simulated fleahopper feeding (i.e., penetrative inoculation), the fleahopper isolate rotted cotton buds. These results indicated the fleahoppers are vectors of opportunistic $P$. ananatis strains causing loss of the cotton fruiting structures.
\end{abstract}

\section{Keywords}

Bud Abscission, Opportunistic Pathogens, Gossypium hirsutum

\section{Introduction}

Pantoea ananatis (Serrano) is a Gram negative bacterium that includes strains capable of residing as part of normal microbial flora or infecting various hosts. Reports of both human and plant pathogenic strains are well documented [1]. In 
plant pathology, $P$. ananatis can inflict disease in both monocots and dicots. Studies focused on the potential of cotton fleahoppers (Pseudatomoscelis seriatus Reuter) to vector plant pathogenic $P$. ananatis into cotton are limited in documentation. In research towards dissecting the mechanisms employed by cotton fleahoppers to inflict damage to cotton fruit, we putatively identified $P$. ananatis as the main culprit of disease following insect feeding.

Cotton fleahoppers and other pests that feed via a piercing-sucking mechanism have become significant pests of cotton. In 1999, the cotton fleahopper was ranked as the top cause of cotton yield losses, primarily because of severe losses in Texas in that year [2]. In 2004, these insects were ranked among the top five insect causes of cotton yield losses: Lygus bug (Hahn), \#2; stink bugs (Leach), \#3; and cotton fleahopper, \#5 [3]. More recently, the cotton fleahopper has held its significance as a cotton pest ranking $5^{\text {th }}$ in 2014 [4].

An association between fleahoppers and plant pathogen transmission into cotton flower and leaf buds (i.e., squares) resulting in disease has been suggested by Martin et al. [5]. Subsequent infections cause ethylene bursts resulting in abscission of buds and young bolls. Cotton fleahoppers are infested with various fungi and with bacteria putatively identified as Xanthomonas and Pseudomonas spp. [6] [7] [8]. Unfortunately, criteria for the identification of the bacteria were not provided. The microorganisms were isolated from salivary glands as well as whole insects. Martin et al. [9] reported that fleahoppers fed 5\% sucrose that contained Xanthomonas campestris pv. malvacearum both acquired and subsequently transmitted the bacterium to cotton plants causing disease symptoms on leaves and stems. Terminal bud explants of cotton planted in agar in 25-ml flasks showed a burst in ethylene production when infested with fleahoppers, or when inoculated with microorganisms associated with the insect [5] [6] [7]. Pectinase preparations from salivary glands also caused a burst in ethylene synthesis [10]. Ethylene bursts are symptomatic of tissue necrosis incited by microbial infections of plant tissues [11] [12].

Cotton fleahoppers are known to occur throughout the Cotton Belt yet, losses generally occur mostly in Texas followed by Oklahoma, Louisiana, Kansas, and Arizona. This is probably due to the fact that the insects generally prefer weed hosts and move to cotton only when satisfactory weed hosts are not available [13]. In Central Texas, the insect overwinters primarily as eggs inserted into stems of croton (Croton capitatus Michaux), its preferred fall host [14]. When nymphs hatch in the spring, they move to weeds such as horsemint (Monarda punctata L.). Later generations move to cotton in June when the horsemint and other spring weeds begin to senesce. Once cotton ceases to flower, fleahoppers move back to croton for late summer and fall generations.

Bell et al. [14] characterized generally the microorganisms associated with cotton fleahoppers and provided evidence for their involvement in leaf and flower bud abscission. The insects were collected from two weed hosts, horsemint (Monarda punctata L.) and croton, and cotton (Gossypium hirsutum L.) at seven intervals during the 2005 cotton growing season in Texas. Most fleahop- 
pers yielded sufficient bacteria, when washed in sterile water, to cause severe seed rot and internal boll rot of 13 to $15 \mathrm{~d}$ cotton bolls puncture inoculated with the wash water. Initial efforts to identify the Pantoea isolates to species did not render clear results.

In this study, we used a bacterial strain isolated from a fleahopper in simulated insect feeding transmission experiments to test for cotton infectivity. Pantoea species have been distinguished by numerical taxonomy using API systems [15], fatty acid profiles [16] [17], and 16S ribosomal DNA (rDNA) sequence analyses [18] [19]. Here, we employed all of these techniques to characterize Pantoea isolates from laboratory reared insects and diseased buds resulting from feeding of these insects. The likelihood that the cotton fleahopper is actually capable of transmitting cotton pathogens is also discussed.

\section{Materials and Methods}

\subsection{Simulated Fleahopper Feeding Studies}

Strain CFH 7-1R was previously isolated from a field collection of cotton fleahoppers [14]. The strain was determined to be a natural variant resistant to Rif. Bacterial suspensions of strain CFH 7-1R in sterile distilled water were prepared from $18 \mathrm{~h}$ cultures and adjusted spectrophotometrically $\left(\mathrm{A}_{600}=0.5\right)$. Using a 31-gauge needle and syringe (Becton, Dickson and Comp. Sparks, MD) $10 \mu \mathrm{l}$ of the appropriate dilution $\left(10^{3}\right.$ cells) were separately inoculated into flower buds (i.e., 3 - $7 \mathrm{~mm}$ wide squares) to simulated fleahopper feeding puncture. The buds were punctured to a depth of $1-2 \mathrm{~mm}$ through the ovary. Mock inoculations consisted of injections of an equal volume of sterile distilled water. Buds were harvested $1 \mathrm{wk}$ following the inoculations, surface sterilized using $70 \%$ ethanol and then rinsed in sterile water. Using a sterile scalpel, the buds were longitudinally sectioned to observe for any damage. Embryo tissue ( $c a .1 .0 \mathrm{~g}$ ) was transferred into a $1.1 \mathrm{ml}$ micro-tube that contained $0.5 \mathrm{ml} \mathrm{PO}_{4}$ buffer $(0.1 \mathrm{~mol}, \mathrm{pH}$ 7.1) and a sterile $4 \mathrm{~mm}$ stainless steel ball. A second $4 \mathrm{~mm}$ stainless steel ball was added, and the tissue was ground using a 2000 Geno/Grinder (SPEX SamplePrep, Metuchen, NJ, USA) for $5 \mathrm{~min}$ at 1500 strokes per min then 10-fold dilution $\left(\mathrm{PO}_{4}\right.$ buffer) plated on both Trypticase Soy Agar (TSA, Sigma Aldrich, St. Louis, MO) and TSA amended with Rif $(100 \mu \mathrm{g} / \mathrm{ml})$. Tissue from embryos injected with water only was processed as negative controls. After two days of incubation at $28^{\circ} \mathrm{C}$, bacterial colonies were enumerated and recorded as colony forming units (CFU)/g tissue.

\subsection{Caging Insects with Cotton}

Deltapine 493 plants were grown from seeds in the greenhouse under a rigid insect control regime following methods described in Medrano et al. [20]. The cultivar possesses normal cotton leaves, is non-trangenic (i.e., no BT genes) and matures by mid-season. The planting mixture consisted of 181 washed sand, 121 vermiculite, 121 dried peat moss, 11 gypsum, $300 \mathrm{ml}$ dolomitic lime and $50 \mathrm{ml}$ esmigran (Scotts-Sierra Horticultural Products Co., Marysvillee, OH, USA). The 
mixture was distributed into $0.5 \mathrm{~kg}$ plastic pots, saturated with reverse-osmosis water, and then pasteurized using aerated steam $\left(74^{\circ} \mathrm{C}\right)$ for $16 \mathrm{~h}$. Seedlings started in germination towels $\left(48 \mathrm{~h}\right.$ at $\left.30^{\circ} \mathrm{C}\right)$ were transplanted into the planting mixture. Glasshouse cooling and heating thermostats were set at 30 and $20^{\circ} \mathrm{C}$ respectively. Weekly, plants received 150 mg Peter's Peat-Lite Special 15-16-17 containing chelated minor elements (Scotts-Sierra Horticultural Products Co., Marysvillee, OH, USA).

Fleahopper eggs (embedded in croton stems) were collected from croton fields in Brazos County, TX, USA (coordinates $30.59450^{\circ} \mathrm{N}, 96.52081^{\circ} \mathrm{W}$ ) near the city of College Station. The insects were reared in the laboratory using methods detailed in Beerwinkle and Marshall [13]. Insects were provided green beans (Phaseolus vulgaris L.) that had first been washed in a $5 \%$ sodium bicarbonate solution. The beans were replenished every two to three days. For microbe transmission testing, adults were caged over fruiting branches using a styrofoam cylinder enclosed with a section of nylon mesh hose fitted over the cylinder and fruiting branch stem and tied at both ends after three fleahoppers were placed in a cage constructed using methods described in Medrano et al. [21]. After $7 \mathrm{~d}$ the insects were removed from the cages and harvested (see Isolation of Microorganisms from Insects and Cotton). Seven days later flower buds that were retained on the fruiting branches were harvested, surface sterilized in 70\% ethanol, rinsed in sterile water, sectioned longitudinally with a sterile scalpel, and examined for tissue necrosis in the anthers, stigma, and ovary. Both insects and sectioned tissues from individual cages were tested separately for the presence of bacteria (see Isolation of Microorganisms from Insects and Cotton).

\subsection{Isolation of Microorganisms from Insects and Cotton}

Following the caging period, each surviving insect was aseptically placed in $70 \%$ ethanol, agitated periodically (3X) with a vortex mixer ( $5 \mathrm{~s}$ ) and then rinsed in sterile water. The insects were then placed into a $1.1 \mathrm{~mL}$ microtube (SPEX SamplePrep, Metuchen, NJ, USA) that contained $0.5 \mathrm{~mL} \mathrm{PO}_{4}$ buffer $(0.125 \mathrm{M}, \mathrm{pH}$ 7.1) and a sterile $4 \mathrm{~mm}$ stainless steel ball (SPEX SamplePrep, Metuchen, NJ, USA). After adding an identical steel ball and capping, the tubes were placed in a 96 tube-rack for crushing. Pulverization of the insects consisted 1500 strokes $/ \mathrm{min}$ for 5 min using a 2000 Geno/Grinder (SPEX SamplePrep, Metuchen, NJ, USA), and then 10-fold dilution $\left(\mathrm{PO}_{4}\right.$ buffer) plated on both TSA, and TSA amended with Rif. Following two days incubation at $28^{\circ} \mathrm{C}$, microbe colonies were counted and expressed as $\mathrm{CFU} / \mathrm{mg}$ insect. The buds were processed as described above (see Simulated Fleahopper Feeding Studies). Single bacterial colonies of different types of bacteria from separate insects or buds were used for identification and to test pathogenicity and virulence with an emphasis given to the most prevalent bacterial colony type from a sample.

\subsection{Characterization of Bacteria}

Remote colonies of bacteria that were isolated, purified, inoculated, and then 
recovered from diseased buds were used for characterization and/or identification. Colony morphology was observed on TSA, King's B-pectin agar (KBP), and potato dextrose agar containing $0.8 \mathrm{~g} / \mathrm{l}$ of fine $\mathrm{CaCO}_{3}$ (PDAC). Anaerobic growth was determined on a medium containing peptone, $2.0 \mathrm{~g}$; NaCl, $5.0 \mathrm{~g}$; $\mathrm{KH}_{2} \mathrm{PO}_{4}, 0.3 \mathrm{~g}$; agar, $3.0 \mathrm{~g}$; bromothymol blue ( $1 \%$ aqueous solution), $3.0 \mathrm{ml}$; glucose, $1.0 \mathrm{~g}$; and water $1 \mathrm{l}$. Ingredients were dissolved with minimal heat $\left(55^{\circ} \mathrm{C}\right)$, and $5 \mathrm{ml}$ of solution was dispensed into $13 \mathrm{ml}$ glass tubes before sterilizing at $121^{\circ} \mathrm{C}$ and $15 \mathrm{psi}$ for $15 \mathrm{~min}$. The tubes were stabbed with $18 \mathrm{~h}$ bacterial paste cultures using a sterile plastic probe (Argo Technologies, Elgin IL), and the medium was covered immediately with sterile mineral oil (Sigma-Aldrich, St. Louis, MO). Anaerobes acidified the medium within 4 to $8 \mathrm{~h}$ at $30^{\circ} \mathrm{C}$; tubes were scored for anaerobic growth after $24 \mathrm{~h}$. The phenotypic tests were performed using protocols described by Schaad et al. [22]. Representative isolates of different groups of bacteria determined from the above criteria were submitted to the Texas Plant Disease Diagnostic Laboratory for fatty acid methyl ester (FAME) profile analysis. Possible species identification was determined by best fit Similarities (SIM index) test to the database for bacteria, Sherlock Version 4.5 (0209B); TSBA 40 4.10. Gram negative isolates that grew anaerobically also were tested with the API 20E strip (Biomérieux, Hazlewood, MO) to determine putative species identification. Control bacteria for all characterization tests included the type strains for $P$. ananatis (ATCC 33244) and P. agglomerans (ATCC 27155).

\subsection{S Ribosomal DNA Sequencing}

A universal degenerate primer set (16sFXbaI-5' GGTCTAGAAGAGTTTGATCMTGG CTCAG 3'; 16sRNotI-5' CGGCGGCCGCACGGGCGGTGTGTACA $3^{\prime}$ ) was used to amplify a $16 \mathrm{~S}$ rDNA Polymerase Chain Reaction (PCR) product [20]. The $1.5 \mathrm{~K}$ base pair approximate PCR product that was predicted based on E. coli positioning was ligated into the XbaI/NotI sites of the pDrive cloning vector (New England Biolabs Inc., Beverly, MA) and then transformed into $E$. coli strain ER2267 (New England Biolabs Inc., Beverly, MA) by $\mathrm{CaCl}_{2}$ transformation [23]. A Qiagen kit (Valencia, CA) was used for all PCR experiments with an amplification protocol that consisted of an initial denaturation step at $96^{\circ} \mathrm{C}$ for $5 \mathrm{~min}$, followed by 30 cycles of denaturation at $95^{\circ} \mathrm{C}$ for $1 \mathrm{~min}$, annealing at $55^{\circ} \mathrm{C}$ for $1 \mathrm{~min}$, extension at $72^{\circ} \mathrm{C}$ for $1 \mathrm{~min}$, and then a final extension at $72^{\circ} \mathrm{C}$ for 5 min using a PTC-200 DNA Engine Cycler (MJ Research Inc., Waltham, MA). Sequencing was performed at the Institute of Developmental and Molecular Biology, Gene Technologies Laboratory at Texas A\&M University (College Station, TX). The derived 16S rDNA gene sequence data from both strands was edited and assembled using Sequencher 4.8. The generated 16S rDNA sequences from the isolates were compared with type strains (NCBI Accession numbers in parenthesis) for several a subclass of the Proteobacteria species including Pantoea ananatis ATCC 33244 (U80196), Pantoea agglomerans ATCC 27155 (NR_ 114735), Pantoea stewartii ATCC 8199 (U80208), Klebsiella oxytoca ATCC 
13182 (NR_119277.1), Serratia marcescens ATCC 13880 (AB681729.1), Pseudomonas putida ATCC 12633 (AJ308313), and Burkholderia cepacia ATCC 25416 (AB680546). The phylogenetic analysis was performed using MEGA6 [24]. Juke-Cantor distances were calculated and a tree was constructed using the Unweighted Pair Group Method with Average (UPGMA). The tree was constructed to scale, with branch lengths (above the branches) in the same units as those of the evolutionary distances used to infer the phylogenetic tree. Bootstrapping was done for 1000 replicates with confidence levels greater 50\% indicated at the tree internodes.

\section{Results and Discussion}

\subsection{Simulated Cotton Fleahopper Feeding Studies}

A total of 50 buds were injected with sterile water and none showed disease symptoms with nine senescing. Further, microbes were not detected from embryo tissue plated on TSA or TSA amended with Rif. Thus, buds punctured with a 31 gauge needle and injected with sterile water were generally tolerant to the trauma (Figure 1(a)). Conversely, all 50 of the buds inoculated with strain $\mathrm{CFH}$ 7-1R became diseased (Figure 1(b) and Figure 1(c)) with 19 falling from the plant. The bacterial concentration range on both TSA and TSA amended with Rif was $10^{6}-10^{8} \mathrm{CFU} / \mathrm{g}$ tissue indicating that strain $\mathrm{CFH} 7-1 \mathrm{R}$ was both responsible for the infection and the only microorganism present. Therefore, simulated fleahopper inoculation tests showed that the strain CFH 7-1R alone was capable of causing both blight and abscission of inoculated buds (Figure 1(b) and Figure $1(\mathrm{c})$ ). These data suggested that bud blighting may be due to multiple effects including both the previously reported fleahopper feeding induced ethylene bursts [5] and bacterial pathogens deposited during insect enzyme egestion.

\subsection{Caging Insects with Cotton}

Laboratory-reared insects $(n=63)$ caged over fruiting branches caused severe damage to cotton fruiting forms (Figure 2). From 48 pinhead squares (1 to 3

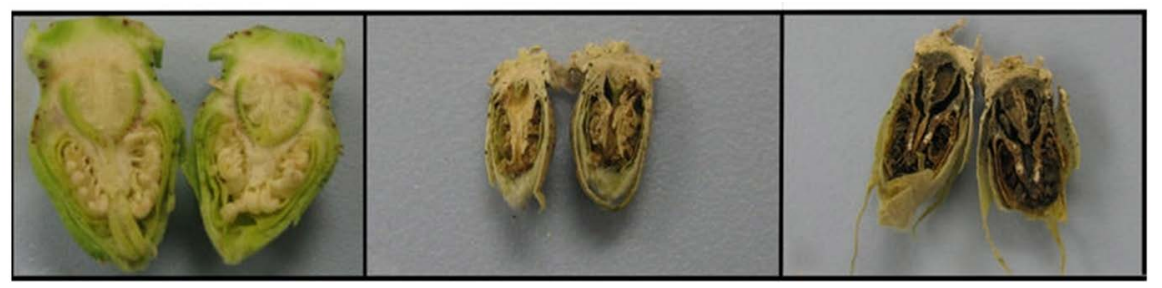

(a)

(b)

(c)

Figure 1. Effects of the introduction of bacterial strain CFH 7-1R into cotton buds via simulated cotton fleahopper puncture inoculation. Simulated cotton fleahopper feeding consisted of inoculation of water or a suspension of strain CFH 7-1R in water at $10^{3} \mathrm{CFU}$ into cotton buds using a 31 gauge needle. Insects harboring strain CFH 7-1R were caged with cotton fruiting branches for seven days. All the buds were harvested seven days after treatments and resulted in the absence of disease if water was used (a). Conversely, tissue necrosis always occurred if CFH 7-1R was puncture inoculated using a needle (b) (c). 


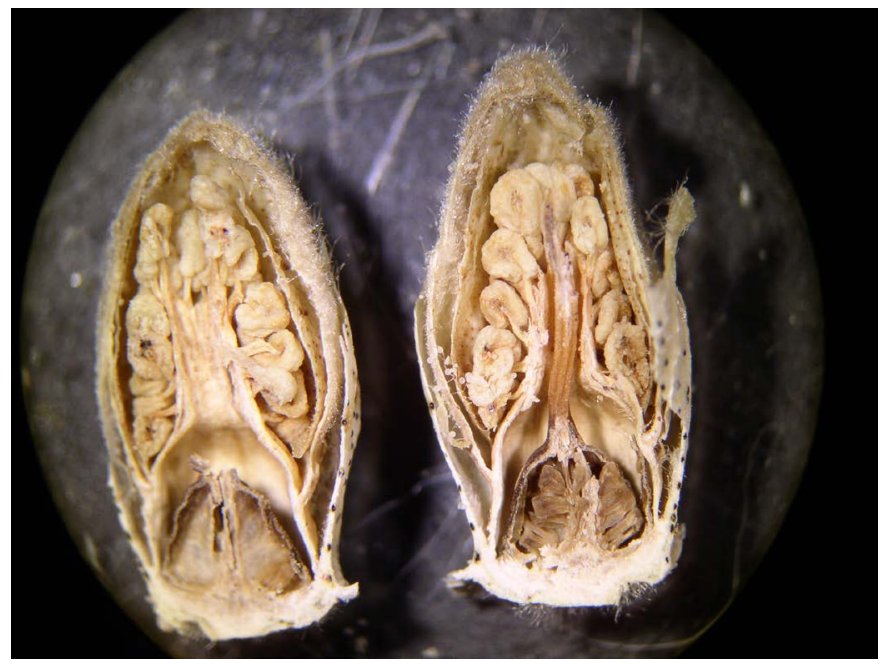

Figure 2. Cross section of cotton flower bud showing rot of ovary wall and damage to anthers following exposure to laboratory reared cotton fleahoppers.

$\mathrm{mm}$ ), all were blighted and killed and 21 abscised with 27 retained on the plant. Fourteen of 29 large flower buds ( 3 to $7 \mathrm{~mm}$ wide) died and abscised. Bacterial concentrations from squares that remained on the plant ranged from $10^{5}-10^{8}$ $\mathrm{CFU} / \mathrm{g}$ tissue on TSA regardless of size. Protuberances from insect feeding or ovipositing appeared on fruiting branches, leaves and flower petals. Abscission was consistently associated with necrosis and damage of the ovary wall (Figure 2). This symptom in abscised squares has been reported previously [25] [26]. Both abscised and retained buds showed necrotic spots among the anthers or on the stigma and style and are considered diagnostic for square abscissions caused by fleahoppers [25] [27]. Damage to the ovary, however, appeared to be most critical for inciting abscission. These results suggested that perhaps opportunistic bacteria are transmitted vertically (i.e., from adult to egg), and thus more advanced lab-reared generations are required to produce cotton "pathogen-free" insects, or a range of bacteria are capable of rotting buds. We are currently exploring each of these possibilities.

\subsection{Characterization of Bacteria}

The laboratory reared fleahoppers were regularly infested with opportunistic bud infecting bacteria. Therefore, 17 isolates from fleahoppers chosen from five insects ( 3 - 4 isolates/bug), 16 isolates from four diseased buds caged (4 isolates/bud) with these insects, and strain CFH 7-1R that was used in the simulated insect feeding studies were characterized microbiologically. From the representative isolates, 27 were Gram-negative rods that produced yellow colonies on TSA. Notably, yellow was the predominant pigmentation on TSA from the original insect and plant tissue isolation plates.

Results that are typical of Pantoea species are shown for nine isolates which are compared with the type strains of $P$. agglomeans and $P$. ananatis in Table 1. All of the putative Pantoea $(\mathrm{n}=27)$ isolates were more similar to $P$. ananatis 
Table 1. Phenotypic and biochemical characteristics of bud and cotton fleahopper isolates that included the Pantoea agglomerans ATCC 27155 and $P$. ananatis ATCC 33244 type strains. Expression of the phenotype and biochemical characteristics are indicated by a positive sign with a negative for non-expression.

\begin{tabular}{|c|c|c|c|c|c|c|c|c|c|c|c|}
\hline & Bud 7 & Bud 11 & Bud 21 & Bud 25 & $\begin{array}{l}\mathrm{CFH} \\
7-1 \mathrm{R}\end{array}$ & $\begin{array}{l}\mathrm{FH} \\
8-1\end{array}$ & $\begin{array}{l}\mathrm{FH} \\
8-3\end{array}$ & FH 14 & FH 16 & $\begin{array}{l}\text { ATCC } \\
27155\end{array}$ & $\begin{array}{l}\text { ATCC } \\
33244\end{array}$ \\
\hline Yellow pigment on TSA & + & + & + & + & + & + & + & + & + & + & + \\
\hline Taupe pigment on YDC & - & - & - & - & - & - & - & - & - & - & - \\
\hline Growth at $37^{\circ} \mathrm{C}$ & + & + & + & + & + & + & + & + & + & + & + \\
\hline Motility & + & + & + & + & + & + & + & + & + & + & + \\
\hline \multicolumn{12}{|l|}{ Production of*: } \\
\hline Beta-galactosidase & + & + & + & + & + & + & + & + & + & + & + \\
\hline Arginine dihydrolase & - & - & - & - & - & - & - & - & - & - & - \\
\hline Lysine decarboxylase & - & - & - & - & - & - & - & - & - & - & - \\
\hline Ornithine decarboxylase & - & - & - & - & - & - & - & - & - & - & - \\
\hline $\mathrm{H}_{2} \mathrm{~S}$ & - & - & - & - & - & - & - & - & - & - & - \\
\hline Deaminase & - & - & - & - & - & - & - & - & - & - & - \\
\hline Indole & + & + & + & + & + & + & + & + & + & - & + \\
\hline Acetoin (Voges-Proskauer) & + & + & + & + & - & + & + & + & + & + & + \\
\hline Gelatinase & - & - & - & - & - & - & - & - & - & - & - \\
\hline Citrate utilization $^{\mathrm{a}}$ & + & - & - & + & + & + & + & - & - & - & + \\
\hline Urea hydrolysis $^{\mathrm{a}}$ & - & - & - & - & - & - & - & - & - & - & - \\
\hline \multicolumn{12}{|l|}{ Acid production from ${ }^{\mathrm{a}}$ : } \\
\hline Glucose & + & + & + & + & + & + & + & + & + & + & + \\
\hline Mannitol & + & + & + & + & + & + & + & + & + & + & + \\
\hline Inositol & + & - & + & - & - & + & - & - & - & - & + \\
\hline Sorbitol & + & + & + & + & + & + & + & + & + & - & + \\
\hline Rhamnose & + & + & + & + & + & + & + & + & + & + & + \\
\hline Sucrose & + & + & + & + & + & + & + & + & + & + & + \\
\hline Melibiose & + & + & + & + & + & + & - & + & + & - & + \\
\hline Amygdalin & + & + & + & + & + & + & - & - & + & + & + \\
\hline Arabinose & + & + & + & + & + & + & + & + & + & + & + \\
\hline Oxidase & - & - & - & - & - & - & - & - & - & - & - \\
\hline
\end{tabular}

${ }^{a}$ Test results were determined using the API $20 \mathrm{E}$ system.

than to $P$. agglomerans. Specifically all produced indole, and all produced acid from sorbitol and melibiose like the type strain of $P$. ananatis. The isolates varied in ability to produce acetoin (20/27), produce acid from inositol (7/27) and utilize citrate (8/27), which are three other distinguishing characters of the type strain of $P$. ananatis (ATCC 33244). Four isolates, Bud 7 and FH 8-1 (Table 1) and Bud 19 and Bud 13 (data not shown) gave test results identical to those of the $P$. ananatis type strain. Based on the API 20E system, the type strain of $P$. 
ananatis had a $65.2 \%$ identification value with Pantoea spp. A similar fit has been observed with most Pantoea isolates from either the field [14] as well as those reared in the laboratory.

The isolates shown in Table 1 also were subjected to fatty acid profile analyses (Table 2) and 16S rDNA sequence analyses (Table 3, Figure 3). Although the FAME profiles of the isolates from fleahoppers were usually most similar to those of $P$. ananatis, the SIM indices generally were very low and not greatly different than those of other species in the Enterobacteriaceae, such as Cedecia species. This is partially illustrated with the type strain of $P$. ananatis having a similarity index of only 0.65 with the database for $P$. ananatis. However, fatty acid profiles of various genera of Enterobacteriaceae also are very similar and of limited value in identifying species from this family. Conversely, the $16 \mathrm{~S}$ rDNA data clearly show that Pantoea isolates from fleahoppers and buds diseased after their feeding are putative variants of $P$. ananatis (Table 3, Figure 3). There were a lower number of base substitutions between the bacterial isolates from this study and the $P$. ananatis type strain than the other Proteobacteria species used in the analysis (Table 3 ). Further, the phylogenetic tree constructed based on comparison of a major portion of the $16 \mathrm{~S}$ rDNA sequence clearly indicated a close relationship between the analyzed isolates and $P$. ananatis type strain 33244.

\section{Conclusions}

Our results showed that strain CFH 7-1R that was isolated from a cotton fleahopper is capable of causing boll rot via simulating stink bug transmission [21]. We are currently testing the possibility that cotton fleahoppers can directly transmit the opportunistic CFH 7-1R into buds and young bolls. Laboratoryreared cotton fleahoppers were frequently infested with putative Pantoea anana-

Table 2. Putative bacterial identification based on Fatty Acid Methyl Esterase similarity indices of isolates from flower buds caged with cotton fleahoppers harboring isolate $\mathrm{CFH}$ 7-1R.

\begin{tabular}{|c|c|c|c|c|c|c|c|c|c|c|}
\hline \multirow[b]{2}{*}{ Bacterial Species } & \multicolumn{4}{|c|}{ Bud Isolates } & \multicolumn{5}{|c|}{ Cotton Fleahopper Isolates } & \multirow{2}{*}{$\begin{array}{c}\text { P. ananatis } \\
\text { ATCC } 33244\end{array}$} \\
\hline & 7 & 11 & 21 & 25 & CFH 7-1R & $8-1$ & $8-3$ & 14 & 16 & \\
\hline Pantoea ananatis & - & 0.19 & 0.69 & 0.10 & 0.37 & 0.45 & 0.73 & 0.76 & 0.67 & 0.65 \\
\hline Cedecea davidae & - & 0.15 & 0.52 & 0.11 & 0.28 & 0.48 & 0.53 & 0.58 & 0.47 & 0.52 \\
\hline Cedecea neteri & - & - & - & - & 0.20 & 0.28 & - & - & - & 0.43 \\
\hline Yersinia frederiksenii & - & 0.26 & - & 0.11 & 0.23 & - & - & - & - & - \\
\hline Yersinia pseudotuberculosis & 0.01 & 0.15 & - & 0.08 & - & - & - & - & - & - \\
\hline Enterobacter intermedius & - & 0.23 & - & 0.10 & 0.35 & - & - & - & - & - \\
\hline Serratia liquefaciens & - & 0.16 & - & - & 0.33 & - & - & - & - & - \\
\hline Salmonella typhimurium GC subgroup B & - & 0.16 & - & 0.12 & 0.20 & - & - & - & - & 0.48 \\
\hline Erwinia-carotovora carotovora & 0.01 & - & - & 0.10 & - & - & - & - & - & - \\
\hline Citrobacter freundii & - & - & - & - & 0.20 & - & - & - & - & - \\
\hline
\end{tabular}


Table 3. Distance values for bud and cotton fleahopper isolates and type strains for several a subclass of the Proteobacteria species. The number of base substitutions per site between sequences is shown. Standard error estimates are shown below the diagonal and calculated by a bootstrap method with 1000 replicates. Analyses were conducted using the Jukes-Cantor method in MEGA6 [24].

\begin{tabular}{|c|c|c|c|c|c|c|c|c|c|c|c|c|c|c|c|c|}
\hline & [1] & [2] & [3] & {$[4]$} & [5] & [6] & [7] & [8] & [9] & {$[10]$} & [11] & {$[12]$} & [13] & {$[14]$} & {$[15]$} & [16] \\
\hline [1] Bud 7 & & {$[0.00]$} & {$[0.00]$} & {$[0.00]$} & {$[0.00]$} & {$[0.00]$} & {$[0.00]$} & {$[0.00]$} & {$[0.00]$} & {$[0.00]$} & {$[0.00]$} & {$[0.01]$} & {$[0.00]$} & {$[0.00]$} & {$[0.01]$} & {$[0.01]$} \\
\hline [2] CFH 7-1R & 0.00 & & {$[0.00]$} & {$[0.00]$} & {$[0.00]$} & {$[0.00]$} & {$[0.00]$} & {$[0.01]$} & {$[0.00]$} & {$[0.00]$} & {$[0.00]$} & {$[0.01]$} & {$[0.00]$} & {$[0.00]$} & {$[0.01]$} & {$[0.01]$} \\
\hline [3] Bud 11 & 0.01 & 0.01 & & {$[0.00]$} & {$[0.00]$} & {$[0.00]$} & {$[0.00]$} & {$[0.00]$} & {$[0.00]$} & {$[0.00]$} & {$[0.00]$} & {$[0.01]$} & {$[0.00]$} & {$[0.01]$} & {$[0.01]$} & {$[0.01]$} \\
\hline [4] Bud 21 & 0.00 & 0.00 & 0.00 & & {$[0.00]$} & {$[0.00]$} & {$[0.00]$} & {$[0.00]$} & {$[0.00]$} & {$[0.00]$} & {$[0.00]$} & {$[0.01]$} & {$[0.00]$} & {$[0.00]$} & {$[0.01]$} & {$[0.01]$} \\
\hline [5] Bud 25 & 0.00 & 0.01 & 0.00 & 0.00 & & {$[0.00]$} & {$[0.00]$} & {$[0.00]$} & {$[0.00]$} & {$[0.00]$} & {$[0.00]$} & {$[0.01]$} & {$[0.00]$} & {$[0.00]$} & {$[0.01]$} & {$[0.01]$} \\
\hline [6] FH 8-1 & 0.00 & 0.00 & 0.01 & 0.00 & 0.01 & & {$[0.00]$} & {$[0.00]$} & {$[0.00]$} & {$[0.00]$} & {$[0.00]$} & {$[0.01]$} & {$[0.00]$} & {$[0.00]$} & {$[0.01]$} & {$[0.01]$} \\
\hline [7] $\mathrm{FH} 8-3$ & 0.01 & 0.01 & 0.00 & 0.00 & 0.00 & 0.01 & & {$[0.00]$} & {$[0.00]$} & {$[0.00]$} & {$[0.00]$} & {$[0.01]$} & {$[0.00]$} & {$[0.00]$} & {$[0.01]$} & [0.01] \\
\hline [8] FH 14 & 0.00 & 0.01 & 0.00 & 0.00 & 0.00 & 0.01 & 0.00 & & {$[0.00]$} & {$[0.00]$} & {$[0.00]$} & {$[0.01]$} & {$[0.00]$} & {$[0.00]$} & {$[0.01]$} & [0.01] \\
\hline [9] FH 16 & 0.01 & 0.01 & 0.01 & 0.00 & 0.00 & 0.01 & 0.01 & 0.00 & & {$[0.00]$} & {$[0.00]$} & {$[0.01]$} & {$[0.00]$} & {$[0.00]$} & {$[0.01]$} & [0.01] \\
\hline $\begin{array}{l}\text { [10] Pantoea } \\
\text { ananatis } \\
\text { ATCC } 33244\end{array}$ & 0.00 & 0.00 & 0.00 & 0.01 & 0.01 & 0.00 & 0.01 & 0.01 & 0.01 & & {$[0.00]$} & {$[0.01]$} & {$[0.00]$} & {$[0.00]$} & {$[0.01]$} & {$[0.01]$} \\
\hline $\begin{array}{c}\text { [11] P. agglomerans } \\
\text { ATCC } 27155\end{array}$ & 0.01 & 0.01 & 0.01 & 0.01 & 0.01 & 0.01 & 0.01 & 0.01 & 0.01 & 0.01 & & {$[0.01]$} & {$[0.00]$} & {$[0.00$} & [0.01] & {$[0.01]$} \\
\hline $\begin{array}{c}\text { [12] Burkholderia } \\
\text { cepacia } \\
\text { ATCC } 25416\end{array}$ & 0.19 & 0.18 & 0.18 & 0.18 & 0.18 & 0.19 & 0.18 & 0.18 & 0.18 & 0.19 & 0.19 & & {$[0.01]$} & {$[0.01]$} & {$[0.01]$} & {$[0.01]$} \\
\hline $\begin{array}{c}\text { [13] P. stewartii } \\
\text { ATCC } 8199\end{array}$ & 0.01 & 0.01 & 0.01 & 0.01 & 0.01 & 0.01 & 0.01 & 0.01 & 0.01 & 0.01 & 0.01 & 0.19 & & {$[0.00]$} & {$[0.01]$} & {$[0.01]$} \\
\hline $\begin{array}{c}\text { [14] Klebsiella } \\
\text { oxytoca } \\
\text { ATCC } 13182\end{array}$ & 0.02 & 0.02 & 0.02 & 0.02 & 0.02 & 0.02 & 0.03 & 0.02 & 0.02 & 0.02 & 0.02 & 0.19 & 0.02 & & {$[0.01]$} & {$[0.00]$} \\
\hline $\begin{array}{c}\text { [15] Pseudomonas } \\
\text { putida } \\
\text { ATCC } 12633\end{array}$ & 0.14 & 0.14 & 0.15 & 0.15 & 0.15 & 0.14 & 0.15 & 0.15 & 0.15 & 0.15 & 0.14 & 0.16 & 0.15 & 0.14 & & {$[0.01]$} \\
\hline $\begin{array}{l}\text { [16] Serratia } \\
\text { marcescens } \\
\text { ATCC } 13880\end{array}$ & 0.03 & 0.03 & 0.03 & 0.03 & 0.03 & 0.03 & 0.03 & 0.03 & 0.03 & 0.03 & 0.03 & 0.19 & 0.03 & 0.03 & 0.14 & \\
\hline
\end{tabular}

tis strains that caused severe necrosis and rot of flower buds. Other pathogenic bacteria can be carried by fleahoppers and may also contribute to damage caused by the insect. Cotton fleahoppers apparently introduce these bacteria into ovaries of buds where they cause rot and increase the frequency of subsequent abscission.

The small size of the insect (2.5 to $3 \mathrm{~mm}$ long) might seem to preclude this possibility. However, the proboscis and stylet of the insect is approximately 1.5 $\mathrm{mm}$ long and the distance to the ovary from the outside of even a large bud is usually no more than $1 \mathrm{~mm}$ [28]. We propose that the bacterial infections, especially of the ovary, are likely the primary direct cause of ethylene bursts that occur in squares injured by fleahoppers and may lead to abscission. The pathogenicity of putative $P$. ananatis strains from cotton fleahoppers to other known 


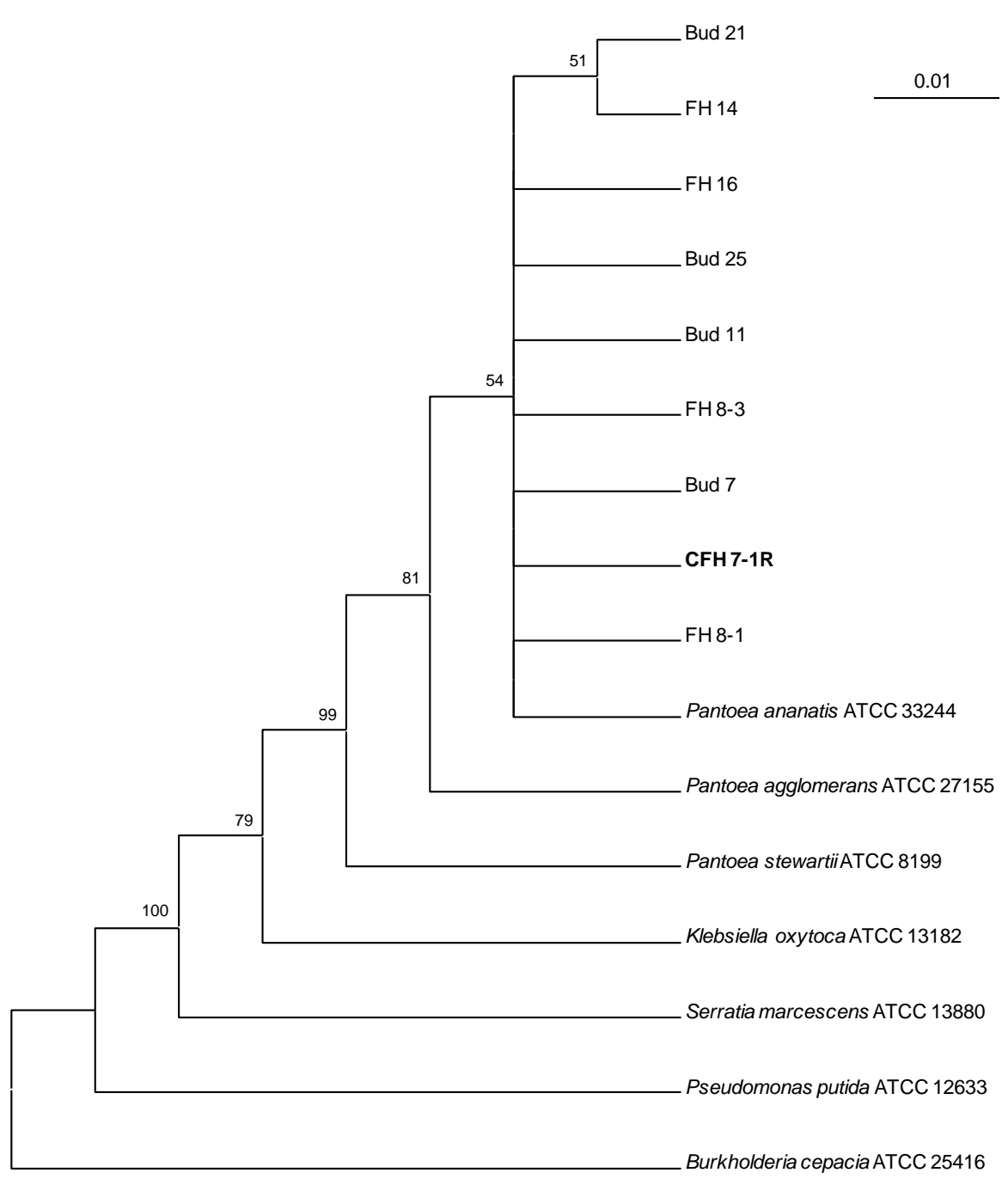

Figure 3. Phylogenetic tree of $16 \mathrm{~S}$ rDNA showing the relationships among the cotton fleahopper and bud isolates, and type strains for several a subclass of the Proteobacteria species. The sequences were aligned using molecular evolutionary genetics analysis (MEGA6) software [24]. Juke-Cantor distances were calculated and the tree was constructed in MEGA6 using the Unweighted Pair Group Method with Average (UPGMA). Bootstrapping was done for 1000 replicates and confidence levels greater than $50 \%$ are indicated at the internodes.

hosts of this bacterium, such as pineapple, melons, and onions is yet to be determined.

\section{Acknowledgements}

The authors are grateful to Jose Quintana, Chris Parker, Kathryn Wittie, Renata Luff and Jordan Dickerson for technical assistance. We also recognize Dr. Larry Barnes for performing the FAME analyses.

\section{References}

[1] Coutinho, T.A. and Venter, S.N. (2009) Pantoea ananatis: An Unconventional Plant Pathogen. Molecular Plant Pathology, 10, 325-335. 
https://doi.org/10.1111/j.1364-3703.2009.00542.x

[2] Williams, M.R. (2000) Cotton Insect Loss Estimates-1999. Proceedings 2000 Beltwide Cotton Conferences, National Cotton Council, 884-887.

[3] Williams, M.R. (2005) Cotton Insect Losses-2004. Proceedings 2005 Beltwide Cotton Conferences, National Cotton Council, 1828-1843.

[4] Williams, M.R. (2015) Cotton Insect Losses-2014. Proceedings 2005 Beltwide Cotton Conferences, National Cotton Council, 494-496.

[5] Martin Jr., W.R., Morgan, P.W., Sterling, W.L. and Kenerley, C.M. (1988a) Cotton Fleahopper and Associated Microorganisms as Components in the Production of Stress Ethylene by Cotton. Plant Physiology, 87, 280-285. https://doi.org/10.1104/pp.87.1.280

[6] Duffey, J.E. and Powell, R.D. (1979) Microbial Induced Ethylene Synthesis as a Possible Factor of Square Abscission and Stunting in Cotton Infested by Cotton Fleahopper. Annals of the Entomological Society of America, 72, 599-601. https://doi.org/10.1093/aesa/72.5.599

[7] Grisham, M.P., Sterling, W.L., Powell, R.D. and Morgan, P.W. (1987) Characterization of Fleahopper (Pseudatomoscelis seriatus [Reuter]) (Hemiiptera: Miridae)-Microorganism Induction of Stress Ethylene Synthesis in Cotton. Annals of the Entomological Society of America, 80, 411-416. https://doi.org/10.1093/aesa/80.3.411

[8] Martin Jr., W.R., Grisham, M.P., Kenerley, C.M., Sterling, W.L. and Morgan, P.W. (1987) Microorganisms Associated with Cotton Fleahopper, Pseudatomoscelis seriatus (Heteroptera: Miridae). Annals of the Entomological Society of America, 80, 251-255. https://doi.org/10.1093/aesa/80.2.251

[9] Martin Jr., W.R., Sterling, W.L., Kenerley, C.M. and Morgan, P.W. (1988c) Transmission of Bacterial Blight of Cotton, Xanthomonas campestris pv. malvacearum, by Feeding of the Cotton Fleahopper: Implications for Stress Ethylene-Induced Square Loss in Cotton. Journal of Entomological Science, 23, 161-168.

[10] Martin Jr., W.R., Morgan, P.W., Sterling, W.L. and Meola, R.W. (1988b) Stimulation of Ethylene Production in Cotton by Salivary Enzymes of the Cotton Fleahopper (Heteroptera: Miridae). Environmental Entomology, 17, 930-935. https://doi.org/10.1093/ee/17.6.930

[11] Hilsop, E.C., Hoad, G.V. and Archer, S.A. (1973) The Involvement of Ethylene in Plant Disease. In: Byrde, R.J. and Cutting, C.V., Eds., Fungal Pathogenicity and the Plants Response, Academic Press, New York, 87-113.

[12] Pegg, C.F. (1976) The Involvement of Ethylene in Plant Pathogenesis. In: Heitfuss, R. and Williams, P.H., Eds., Encyclopedia of Plant Physiology, New Series, Vol. 4, Springer-Verlag, Heidlberg, 582-591.

[13] Beerwinkle, K.R. and Marshall, H.F. (1999) Cotton Fleahopper (Heteroptera: Miridae) Responses to Volatiles from Selected Host Plants. Journal of Cotton Science, 3, 153-159.

[14] Bell, A.A., Lopez, J.D. and Medrano, E.G. (2006) Frequency and Identification of Cotton-Rotting Bacteria from Cotton Fleahoppers. Proceedings of the Beltwide Cotton Conferences, San Antonio, 3-6 January 2006, 97-104.

[15] Mergaert, J., Verdonck, L., Kersters, K., Swings, J., Boeufgras, J.M. and De Ley, J. (1984) Numerical Taxonomy of Erwinia Species Using API Systems. Journal of General Microbiology, 130, 1893-1910. https://doi.org/10.1099/00221287-130-8-1893

[16] Kado, C.I. (2006) Erwinia and Related Genera. In: Dworkin, M., Falkow, S., Rosenberg, E., Schleifer, K.-H. and Stackebrandt, E., Eds., The Prokaryotes: Proteobacte- 
ria: Gamma Subclass, 3rd Edition, Springer Verlag, Heidlberg, New York, 443-450. https://doi.org/10.1007/0-387-30746-x 15

[17] Mergaert, J., Verdonck, L. and Kersters, K. (1993) Transfer of Erwinia ananas (Synonym, Erwinia uredovora) and Erwinia stewartii to the Genus Pantoea emend. As Pantoea ananas (Serrano 1928) comb. Nov., and Pantoea stewartii (Smith 1898) comb. Nov. International Journal of Systematic Bacteriology, 43, 162-173. https://doi.org/10.1099/00207713-43-1-162

[18] Kwon, S.W., Go, S.J., Kang, H.W., Ryu, J.C. and Jo, J.K. (1997) Phylogenetic Analysis of Erwinia Species Based on 16S rRNA Gene Sequences. International Journal Systematic Bacteriology, 47, 1061-1067. https://doi.org/10.1099/00207713-47-4-1061

[19] Mergaert, J., Hauben, L., Cnockaert, M.C. and Swings, J. (1999) Reclassification of Non-pigmented Erwinia hericola Strains from Trees as Erwinia billingiae sp. Nov. International Journal Systematic Bacteriology, 49, 377-383. https://doi.org/10.1099/00207713-49-2-377

[20] Medrano, E.G. and Bell, A.A. (2007) Role of Pantoea agglomerans in Opportunistic Bacterial Seed and Boll Rot of Cotton (Gossypium hirsutum) Grown in the Field. Journal of Applied Microbiology, 102, 134-143. https://doi.org/10.1111/j.1365-2672.2006.03055.x

[21] Medrano, E.G., Esquivel, J.F., Bell, A.A., Greene, J.K., Roberts, P.M., Bacheler, J.A., Marios, J.J., Wright, D.L. and Nichols, R.L. (2009) Potential for Nezara viridula (Hemiptera: Pentatomidae) to Transmit Bacterial and Fungal Pathogens into Cotton Bolls. Journal of Economic Entomology, 59, 405-412.

[22] Schaad, N.W., Jones, J.G. and Chen, W. (2001) Laboratory Guide for Identification of Plant Pathogenic Bacteria. 3rd Edition, APS Press, St. Paul.

[23] Sambrook, J., Fritsch, E.F. and Maniatis, T. (1989) Molecular Cloning. A Laboratory Manual. Cold Spring Harbor Laboratory Press, New York.

[24] Tamura, K., Stecher, G., Peterson, D., Filipski, A. and Kumar, S. (2013) MEGA6: Molecular Evolutionary Genetics Analysis (MEGA) Software Version 6.0. Molecular Biology and Evolution, 30, 2725-2729. https://doi.org/10.1093/molbev/mst197

[25] Mauney, J.R. and Henneberry, T.J. (1979) Identification of Damage Symptoms and Patterns of Feeding of Plant Bugs in Cotton. Journal of Economic Entomology, 72, 496-501. https://doi.org/10.1093/jee/72.4.496

[26] Mauney, J.R. and Henneberry, T.J. (1984) Causes of Square Abscission in Cotton in Arizona. Crop Science, 24, 1027-1030. https://doi.org/10.2135/cropsci1984.0011183X002400060006x

[27] Williams, L. III., Phillips, J.R. and Tugwell, N.P. (1987) Field Technique for Identifying Causes of Pinhead Square Shed in Cotton. Journal of Economic Entomology, 80, 527-531. https://doi.org/10.1093/jee/80.2.527

[28] Smith, C.W. and Cothren, J.T. (1999) Cotton: Origin, History, Technology, and Production. John Wiley \& Sons, New York. 
Submit or recommend next manuscript to SCIRP and we will provide best service for you:

Accepting pre-submission inquiries through Email, Facebook, LinkedIn, Twitter, etc. A wide selection of journals (inclusive of 9 subjects, more than 200 journals)

Providing 24-hour high-quality service

User-friendly online submission system

Fair and swift peer-review system

Efficient typesetting and proofreading procedure

Display of the result of downloads and visits, as well as the number of cited articles Maximum dissemination of your research work

Submit your manuscript at: http://papersubmission.scirp.org/

Orcontact as@scirp.org 